\section{An In Vivo Analysis of Pancreatic Protein and Insulin Biosynthesis in a Rat Model for Non-Insulin-dependent Diabetes}

\author{
M. Alan Permutt, Keiji Kakita, Philip Malinas, \\ Irene Karl, Susan Bonner-Weir, Gordon Weir, \\ and Stephen J. Giddings \\ Department of Internal Medicine, Washington University School \\ of Medicine, St. Louis, Missouri 63110; Medical College \\ of Virginia, Richmond, Virginia 23298; and Washington \\ University Medical Service, US Veterans Administration \\ Medical Center, St. Louis, Missouri 63125
}

senger RNA (mRNA) was estimated as the rate of insulin biosynthesis in control and diabetic animals. There was a $61 \%$ reduction in proinsulin mRNA at 4 wk and an $85 \%$ reduction at $7 \mathrm{wk}(P<0.001)$ in the diabetic animals.

After streptozotocin injection in neonatal rats, there is marked $\beta$-cell damage and hyperglycemia. $\beta$-cell regeneration occurs with return to normoglycemia, but with age hyperglycemia develops. The reduction in insulin synthesis and proinsulin mRNA seemed disproportionate with the more modest reduction in $\beta$-cell number. The importance of these observations is that, in this animal model, diabetes is associated with a limited ability to regenerate $\beta$-cell mass and to synthesize insulin. The relationship between the defect in glucose-stimulated insulin release and impaired insulin biosynthesis has yet to be determined.

\section{Introduction}

While juvenile onset (insulin-dependent) and adult onset (noninsulin-dependent) diabetes (IDD and NIDD, respectively) ${ }^{1}$ are probably different diseases (1-4), they share the common pathophysiological characteristic of either relative or absolute insulin deficiency. The lack of insulin in IDD is associated with a marked reduction in pancreatic $\beta$-cell mass (5). The relationship between $\beta$-cell number and NIDD is less clear. Several studies based on autopsy specimens of pancreas have recorded an $\sim 50-60 \%$ decrease in insulin content (6-8) as well as in $\beta$-cell number (9) in NIDD. Because man may tolerate up to $90 \%$ pancreatectomy without carbohydrate intolerance (10-12), a 50\% reduction in $\beta$-cell mass might not produce a lack of insulin, unless it coexisted with a functional defect in the remaining $\beta$ -

1. Abbreviations used in this paper: IDD, insulin-dependent diabetes; NIDD, non-insulin-dependent diabetes. 
cells. The $\beta$-cell defect in NIDD could be impaired synthesis that causes impaired secretion of insulin.

Insulin secretory defects in NIDD have been extensively documented. Porte $(14,15)$ and others $(16,17)$ have evaluated plasma insulin responses to acute and chronic glucose administration. Insulin response to acute glucose challenge is markedly diminished, while basal and steady state plasma insulin levels after prolonged glucose administration in NIDD do not differ from levels in nondiabetics (14). A defect in basal and steady state insulin release is present in NIDD because insulin levels are comparable to those in IDD only at the expense of considerable hyperglycemia. It was suggested that basal and steady state insulin output after long-term changes in glucose metabolism might be related to insulin synthesis (14). Virtually nothing is known, however, of the relationship between synthesis and secretion of insulin in man.

An animal model for NIDD was recently described (18). Streptozotocin injected into 2 -d-old rats produces acute hyperglycemia and a markedly reduced percentage of $\beta$-cells within the islets. By 2 wk there is substantial regeneration of $\beta$-cells and the plasma glucose returns to normal. $\beta$-cell number does not return to normal but is maintained at $50-75 \%$ of control values. By 6 wk of age the streptozotocin-treated rats again become hyperglycemic. Studies of insulin secretion revealed a selective impairment of glucose-stimulated insulin secretion with the preservation of responses to other agents (19). Similar modest reductions in $\beta$-cell number, pancreatic insulin content, and impaired glucose-stimulated insulin release are prominent features of nonketotic hyperglycemic diabetes in man, though the etiology of the two syndromes may be entirely different.

This hyperglycemic rat model provides an opportunity to explore the relationship between glucose-stimulated insulin secretion and synthesis. One might predict that insulin synthesis would decrease in this model after injection of streptozotocin, a known potent $\beta$-cell toxin. Yet one study found that insulin synthesis increased in these diabetic animals (20). Unfortunately, the only method of measuring synthesis in this and most other studies involves measuring labeled amino acid incorporation into insulin in isolated islets incubated in vitro. The present series of experiments provides the first assessment of insulin biosynthesis in vivo in any animal model for NIDD and avoids many pitfalls inherent in extending observations made in collagenase-digested islets in vitro to their function in vivo. The results presented here suggest a significant impairment of insulin synthesis.

\section{Methods}

Non-insulin-dependent diabetic animals with normal fasting blood sugars and elevated fed blood sugars were produced as previously described (18). 2-d-old Sprague-Dawley pups were injected intraperitoneally with streptozotocin $(90 \mathrm{mg} / \mathrm{kg}$ in $0.1 \mathrm{M}$ citrate buffer, $\mathrm{pH} 4.5$; Dr. William E. Dulin, Upjohn Company, Kalamazoo, MI). Controls were injected with an equal volume of citrate buffer. Animals were weaned at $24 \mathrm{~d}$. Blood was taken from the animals at the time of sacrifice for plasma glucose, which was determined by a standard glucose oxidase method (18). The animals were fed Purina Rat Chow (Ralston Purina Co., St. Louis, MO) until the time of sacrifice. Pancreas was homogenized in $70 \%$ acid alcohol with a polytron homogenizer, and immunoreactive insulin was measured by a double antibody radioimmunoassay that (21) used rat insulin as a standard (Novo Research Institute, Copenhagen, Denmark). Protein determinations on acid alcohol extracts were performed by the method of Lowry et al. (22).

Insulin biosynthesis. Pancreas from 7-wk-old animals was excised, minced into $1 \mathrm{~mm}^{3}$ pieces with scissors, and incubated in $\left[{ }^{3} \mathrm{H}\right]$ leucine at $100 \mu \mathrm{Ci} / \mathrm{ml}$ (New England Nuclear, Boston, $\mathrm{MA} ; 141 \mathrm{Ci} / \mathrm{mmol}$ ) in $0.5 \mathrm{ml}$ of Krebs-Ringer bicarbonate buffer at $37^{\circ} \mathrm{C}$ for $1 \mathrm{~h}$ in an atmosphere of $95 \% \mathrm{CO}_{2} / 5 \% \mathrm{O}_{2}$. All experiments were performed on fed rats between $10 \mathrm{a} . \mathrm{m}$. and noon. After incubation the tissue was washed, extracted in acid alcohol, and aliquots were analyzed for $\left[{ }^{3} \mathrm{H}\right]$ leucine incorporation into total protein by precipitation with TCA, or into proinsulin and insulin by precipitation with antiinsulin serum as previously described $(23,24)$.

It is more difficult to measure insulin synthesis in whole pancreas than in isolated islets, since insulin represents only $\sim 0.1 \%$ of total pancreas protein, compared with $\sim 10 \%$ of islet protein. Therefore, to lower nonspecific binding during immunoprecipitation, aliquots of labeled pancreatic protein were immunoprecipitated with antiinsulin serum and second antibody as described (23). This precipitate was dissolved in dilute acid, split into equal fractions, neutralized, and reprecipitated with antiinsulin serum or nonimmune serum. Nonimmune serum controls were $<20 \%$ of antiinsulin serum precipitates. For in vivo measurements (see below), background nonspecific binding was further reduced by chromatographing the acid-alcohol extract and immunoprecipitating only the labeled protein migrating in the proinsulin region.

In vivo measurement of insulin biosynthesis. Insulin biosynthesis was measured in vivo by a modification of the method of Peavy et al. (25) for measurement of albumin synthesis in diabetic rat liver. 4-wkold rats that weighed $\sim 100 \mathrm{~g}$ were injected intraperitoneally with $\left[{ }^{3} \mathrm{H}\right]$ leucine $(1 \mathrm{mCi} / 100 \mathrm{~g}$ body $\mathrm{wt}$.) and $45 \mathrm{~min}$ later pancreases were removed and extracted with acid alcohol. $\left[{ }^{3} \mathrm{H}\right]$ Leucine incorporation into total pancreatic protein was determined on the acid-alcohol soluble fraction by precipitation with TCA as above. The extracts were then lyophilized, dissolved in 400-500 $\mu \mathrm{l}$ of $1 \mathrm{M}$ acetic acid, and chromatographed on a Sephadex G-50 column (Pharmacia Fine Chemicals, Inc. Piscataway, NJ) as previously described (23). Because the $\left[{ }^{3} \mathrm{H}\right]$ leucine incorporation was limited to a 45 -min period, no conversion of labeled proinsulin to insulin was observed. Separation of insulin and proinsulin on the column into two distinct peaks had been demonstrated previously. To facilitate immunoprecipitation of $\left[{ }^{3} \mathrm{H}\right]$ proinsulin, fractions that contained $\left[{ }^{3} \mathrm{H}\right]$ proinsulin were separated from unlabeled insulin and aliquots were precipitated with either antiinsulin serum or nonimmune serum. $\left[{ }^{3} \mathrm{H}\right]$ Leucine incorporation into immunoprecipitable proinsulin in 10 animals ranged from 130 to $1,424 \mathrm{cpm}$ per pancreas, and incorporation into total pancreatic protein from 56,000 to $380,000 \mathrm{cpm}$ per pancreas.

Protein synthesis in whole pancreas in vivo. Pancreatic protein synthesis was measured in vivo by the method of McNurlan, et al., in which large doses of leucine are used in an attempt to eliminate the inaccurate estimates of rates that are caused by variations in precursor pools encountered with tracer amounts of labeled amino acids (26). While this is only an assumption, these authors have shown that in rats with massive doses of injected labeled amino acid, the specific activities in liver and jejunal mucosa were proportional to the specific activity of what was injected, as well as to that measured in plasma. In our experiments we found the same relationship between the specific activity of the injected dose and that measured in plasma and pancreas. 10 
Sprague-Dawley rats that weighed $\sim 100 \mathrm{~g}$ each were injected with 1 $\mathrm{ml} / 100 \mathrm{~g}$ body wt. of $100 \mathrm{mM}$ leucine in water that contained $50 \mu \mathrm{Ci} /$ $\mathrm{ml}$ of $\left[{ }^{3} \mathrm{H}\right]$ leucine. Conscious animals were restrained and injected in a lateral tail vein. Animals were sacrificed by decapitation, four $2 \mathrm{~min}$, and six $10 \mathrm{~min}$, after injection. The pancreases were quickly excised and frozen in liquid nitrogen. These steps were repeated with the 10 rats that had previously been starved for $48 \mathrm{~h}$ and with 10 diabetic rats. The pancreases were homogenized in $12 \%$ perchloric acid, centrifuged at $2,800 \mathrm{~g}$ for $15 \mathrm{~min}$, and the supernate was used to measure specific activity of free leucine. Protein, RNA, and protein-bound leucine were determined on the perchloric acid-insoluble precipitate (26). The specific activity of leucine in the free leucine pool was determined by the method of Beaucamp et al. (27). The specific activity of protein-bound leucine was similarly determined after extensive washing of the precipitate with unlabeled leucine and TCA, followed by hydrolysis in $6 \mathrm{M} \mathrm{HCl}$ at $110^{\circ} \mathrm{C}$ for $24 \mathrm{~h}$. All radioactivity measurements were made in a liquid scintillation counter in aqueous-based scintillation fluid.

Calculations of the rate of synthesis $\left(K_{\mathrm{s}}\right)$ were as described by McNurlan et al. (26). The equation, $K_{\mathrm{s}}=S_{\mathrm{b}} / S_{\mathrm{at}} \times 100$ was used. $S_{\mathrm{b}}$ is the specific radioactivity of leucine in protein, $S_{\mathrm{a}}$ is the mean specific radioactivity of leucine in the precursor pool, and $t$ is the time (10 min) expressed in days. The specific mean radioactivity of the precursor $\left(S_{\mathrm{a}}\right)$ was taken to be the specific radioactivity of free leucine from the tissue homogenate. This was an average value obtained by killing four animals at $2 \mathrm{~min}$ and six animals at $10 \mathrm{~min}$ and assuming a linear change in specific activity over that time.

Isolation of RNA. Pancreases were weighed and immediately homogenized for $30 \mathrm{~s}$ at high speed with a polytron homogenizer (Brinkmann Instruments, Inc., Westbury, NY) in $10 \mathrm{ml}$ of buffer $4 \mathrm{M}$ guanidine thiocyanate (Fluka, AG, Basel, Switzerland); $25 \mathrm{mM}$ sodium citrate, pH 7.0; 0.1 M 2-mercaptoethanol (Eastman Kodak Co., Rochester, NY); and $0.33 \%$ anti-foam A (Sigma Chemical Co., St. Louis, MO) according to the method of Chirgwin et al. (28). RNA was purified, and samples were diluted with sterile water to a final concentration of $\sim 5$ $\mathrm{mg} / \mathrm{ml}$ and stored at $-70^{\circ} \mathrm{C}$ until further analysis. Pancreatic protein and RNA content were determined from aliquots $(100 \mu \mathrm{l})$ of the initial homogenate precipitated on ice with $1 \mathrm{ml}$ of $10 \%$ TCA at $4^{\circ} \mathrm{C}$ as previously described $(28,29)$. RNA concentration was determined by absorbance at $260 \mathrm{~nm}$. Pancreatic RNA from each rat $(20 \mu \mathrm{g})$ was glyoxylated according to the method of McMaster and Carmichael (29), electrophoresed on $2 \%$ agarose gels, transferred to diazophenylthio paper, and hybridized as previously described $(30,31)$. The 450 -base-pair insert from pCRI 354 that contained 354 bases of DNA complementary to rat proinsulin I messenger RNA (mRNA) was removed from the parent plasmid pBR 322 by digestion with Hind III and electrophoresed on agarose gels. The insert was labeled with $\left[{ }^{32} \mathrm{P}\right]$ deoxynucleotides by nick translation (32) to $\sim 5-6 \times 10^{8} \mathrm{cpm} / \mathrm{mg}$ and used as a hybridization probe. After hybridization, filters were washed and air dried. Autoradiography was performed using preflashed Kodak XAR film (Eastman Kodak Co.) and Chronex intensifying screens (Dupont Instruments, Wilmington, DE). Proinsulin mRNA was quantitated by use of insulinoma mRNA as a standard and densitometric tracing of the radioautographs (31).

\section{Results}

In vivo assessment of pancreatic protein and insulin biosynthesis rates

Insulin biosynthesis relative to total pancreatic protein synthesis. The streptozotocin-treated rats did not differ at 4 wk from controls in body weight or fasting plasma glucose, but they did have significant hyperglycemia in the fed state and after glucose injection (Table I). Pancreatic insulin content was reduced 35\% in the diabetic animals. To assess the ability of the entire population of islets to synthesize insulin rather than only of those isolated after collagenase digestion, insulin biosynthesis was measured by incubating minces of whole pancreas in $\left[{ }^{3} \mathrm{H}\right]$ leucine over a 1-h period. The relative rate of insulin synthesis in diabetic animals seemed to be reduced compared with that in control pancreas, but the differences were not significant (data not shown).

The finding of increased synthesis in isolated islets of diabetic rats previously reported (20) was not observed in minces of whole pancreas. This suggested that isolated islet experiments may not adequately assess synthesis in vivo. Further experiments were therefore designed to assess the rate of synthesis in vivo in control and diabetic animals. Insulin biosynthesis was measured in vivo by injecting $\left[{ }^{3} \mathrm{H}\right]$ leucine $(1 \mathrm{mCi})$ into $100-\mathrm{g}$ rats and comparing its incorporation into proinsulin with that into total pancreatic protein as described in Methods. The rate of

Table I. Effect of Diabetes on Body Weight, Plasma Glucose, and Pancreatic Immunoreactive Insulin (IRI) in Rats at 4 and 7 Wk of Age

\begin{tabular}{|c|c|c|c|c|c|c|c|c|}
\hline \multirow[b]{2}{*}{ Animals } & \multirow[b]{2}{*}{ Age } & \multirow[b]{2}{*}{ Body wt } & \multicolumn{3}{|l|}{ Plasma glucose } & \multicolumn{3}{|l|}{ Pancreas } \\
\hline & & & Fasting & Fed & $\begin{array}{l}50 \mathrm{~min} \text { after } \\
\text { glucose injection }\end{array}$ & $\mathrm{wt}_{\mathrm{t}}$ & IRI & \\
\hline & $w k$ & $g$ & $m g / d l$ & $m g / d l$ & $m g / d l$ & $g$ & $\mu g / g$ & $\mu g /$ pancreas \\
\hline C & 4 & $86 \pm 6(11)$ & $97 \pm 4(11)$ & $139 \pm 7 \quad(10)$ & $137 \pm 10$ & $0.47 \pm 0.05(6)$ & $63 \pm 8 \quad(6)$ & $28 \pm 2$ \\
\hline SZ & & $74 \pm 2(14)$ & $100 \pm 3(14)$ & $186 \pm 13^{*}(14)$ & $323 \pm 13 \ddagger(14)$ & $0.42 \pm 0.02(7)$ & $41 \pm 2^{*}(7)$ & $18 \pm 1^{*}$ \\
\hline C & 7 & $225 \pm 9(8)$ & - & $135 \pm 4$ & & $1.02 \pm 0.07$ & $28 \pm 3$ & $27 \pm 2$ \\
\hline SZ & & $214 \pm 6(13)$ & - & $207 \pm 21^{*}(13)$ & & $0.99 \pm 0.04(7)$ & $22 \pm 2$ & $23 \pm 2$ \\
\hline
\end{tabular}

C, control; SZ, streptozotocin treated. Data are expressed as mean \pm SEM. $(n)$, number of animals for each determination. $* P<0.05$ different from control; $\ddagger P<0.001$. 
Table II. In Vivo Assessment of Insulin Biosynthesis and Proinsulin mRNA in Streptozotocin-treated (SZ) and Control (C) Rats

\begin{tabular}{llllc}
\hline Animals & Age & Insulin biosynthesis & RNA & Proinsulin mRNA \\
\hline & $w k$ & AIS/total $\times 100$ & mg/pancreas & $n g / m g R N A$ \\
& & $0.391 \pm 0.070(8)$ & $5.41 \pm 1.1(3)$ & $8.76 \pm 0.80(3)$ \\
C & 4 & $0.188 \ddagger \pm 0.015 \ddagger(8)$ & $6.21 \pm 0.5(8)$ & $3.44 \pm 0.60(8)^{*}$ \\
SZ & 4 & - & $5.99 \pm 1.2(4)$ & $18.68 \pm 3.3(4)$ \\
C & 7 & - & $6.50 \pm 1.8(6)$ & $2.87 \pm 0.32(6)^{*}$ \\
SZ & 7 & - & &
\end{tabular}

$\left[{ }^{3} \mathrm{H}\right]$ Leucine $(1 \mathrm{mCi})$ was injected intraperitoneally and 45 min later pancreas was extracted with acid alcohol and $\left[{ }^{3} \mathrm{H}\right]$ leucine incorporated into immunoprecipitable insulin (AIS), and total protein was determined. Proinsulin mRNA was measured by hybridization analysis of total pancreatic RNA as described in Fig. 1 and Methods. $(n)$, number of animals studied.

$* P<0.001$ different from control.

$\ddagger P<0.05$ different from control.

insulin biosynthesis relative to total acid ethanol soluble pancreatic protein was $0.391 \pm 0.07 \%$ in control rats and $0.188 \pm 0.015 \%(P<0.05)$ in the diabetic animals (Table II).

Absolute rate of total pancreatic protein synthesis. The assessment of insulin biosynthesis in vivo described above would not detect an effect of diabetes on total pancreatic protein synthesis. Pancreatic protein synthesis was therefore measured independently using enough amino acid precursor to overwhelm the effects of labeling that differences in pools of endogenous amino acids might cause. The technique is described in detail in Methods. The $K_{\mathrm{s}}$ is the percentage of the total protein in the pancreas that is synthesized per day. Control animals synthesized $185 \%$ of their pancreatic protein per day; this indicates that there is almost a complete turnover of protein every $12 \mathrm{~h}$ (Table III). The $K_{\mathrm{s}}$ for diabetic animals was not significantly lower than for control animals. In contrast, the fractional rate of protein synthesis was reduced 2.5 -fold to $71 \%(P<0.01)$ in rats starved for $2 \mathrm{~d}$. The finding that $2 \mathrm{~d}$ of starvation had a marked effect on the rate of pancreatic protein synthesis, whereas the rate in diabetic animals did not differ from that in controls, indicated that the reduced relative rate of insulin synthesis measured by $\left[{ }^{3} \mathrm{H}\right]$ leucine incorporation was probably a valid assessment of the rate of insulin biosynthesis in control and diabetic rats.

\section{Proinsulin $m R N A$ in control and diabetic rats}

Previous experiments with fed, fasted, refed (33), or glucoseinjected rats (31) had suggested that the amount of proinsulin mRNA was proportional to insulin biosynthesis under these conditions. Proinsulin mRNA concentrations were therefore determined as another assessment of insulin biosynthesis in the diabetic animals. This was done by RNA blot hybridization analysis with ${ }^{32} \mathrm{P}$-labeled cloned rat insulin complementary DNA (cDNA). After hybridization, proinsulin mRNA was quantitated by autoradiography (Fig. $1 \mathrm{~A}$ ) and densitometric analysis. There was $61 \%$ less $(P<0.001)$ proinsulin mRNA at 4 wk and $85 \%$ less $(P<0.001)$ at $7 \mathrm{wk}$ in diabetic than in control animals (Figs. 1 and 2 and Table II). The decrease at 4 wk in mRNA levels correlated closely with the decrease in $\left[{ }^{3} \mathrm{H}\right]$ leucine incorporation into proinsulin ( $52 \%$ reduced, Fig. 3 ).

\section{Discussion}

In vivo assessment of pancreatic protein and insulin biosynthesis. The current experiments provide a way to assess rates of insulin biosynthesis in vivo. A similar method was used to assess in vivo albumin synthesis in diabetic rats (25). Incorporation of labeled amino acid into albumin was measured and compared with that into total liver protein. A marked decrease in albumin synthesis that was found in diabetic rats occurred in parallel with decreased albumin mRNA. Presumably, in the liver albumin and total liver proteins are synthesized from the same precursor pool. Use of this method to assess insulin biosynthesis may be limited by the fact that pancreatic amino acid pools may not reflect those in endocrine islets. Because insulin synthesis is only a fraction of $1 \%$ of total pancreatic protein synthesis (Table III), we injected a large amount of $\left[{ }^{3} \mathrm{H}\right]$ leucine $(1 \mathrm{mCi})$ into relatively small rats $(100 \mathrm{~g})$ to obtain measurable incorporation into immunoprecipitable insulin. The only other measurement of insulin biosynthesis in vivo was that of Logothetopoulos and Jain (34), who injected $2.5 \mathrm{mCi}$ of $\left[{ }^{3} \mathrm{H}\right]$ leucine into a smaller number of larger rats. The cost of these experiments is clearly a limiting factor. Furthermore, it is impossible to measure changes in specific activity of the immediate amino acid precursor pool within islets in vivo. Leucine pools measured in isolated islets after in vivo injection would not be representative of those that occur in vivo because of the time required

Table III. Effect of $2 d$ of Starvation or Diabetes on Protein Synthesis in Pancreas of 4-wk-old Rats

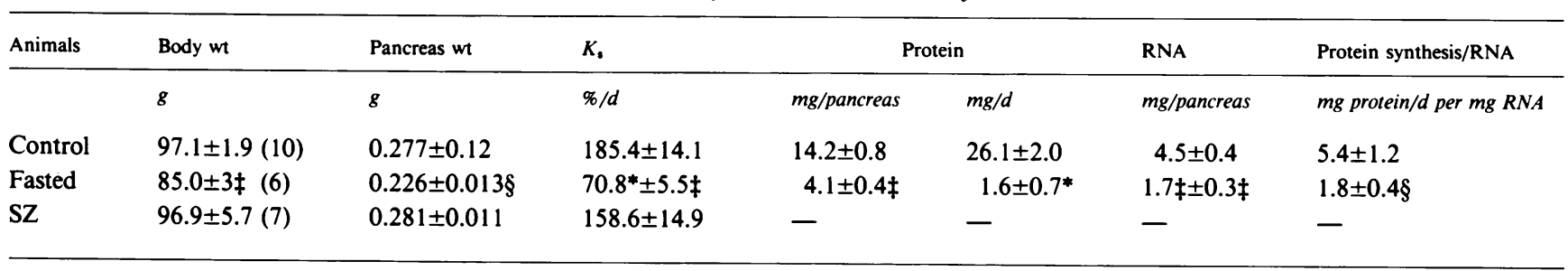

The fractional rate of protein synthesis, $K_{\mathrm{s}}$, in percentage per day $( \pm \mathrm{SEM})$ was measured in control, 2-d starved, and streptozotocin-treated (SZ) diabetic rats after injection of $100 \mu \mathrm{mol}$ of $\left[{ }^{3} \mathrm{H}\right]$ leucine $/ 100 \mathrm{~g}$ body wt as described in Methods. ${ }^{*} P<0.001 ; \quad ¥ P<0.01 ; \S P<0.05$. 


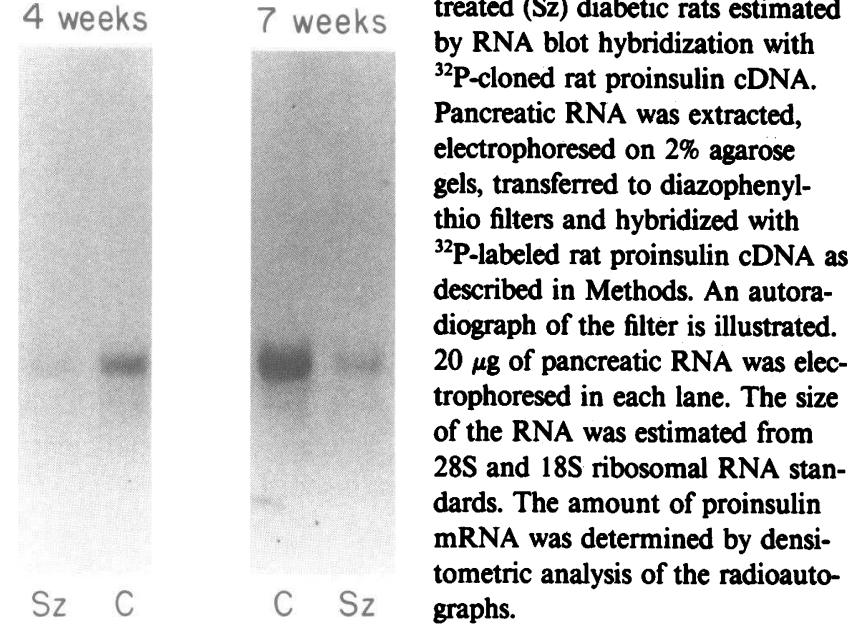

for the islet preparation (at least $1 \mathrm{~h}$ ). Thus, amino acid incorporation into insulin cannot be equated with absolute rates of biosynthesis and can provide only another estimate. The amino acid incorporation studies in this report suggest decreased synthesis of insulin in the diabetic animals, which correlates well with the observed decrease in plasma, pancreatic insulin, and proinsulin mRNA.

Other ways to assess rates of insulin biosynthesis have obvious limits as well. Isolated islets have proved invaluable in elucidating the molecular steps involved in insulin biosynthesis and its control (35-40), yet rates of synthesis estimated in isolated islets in vitro may bear little relationship to rates in vivo. In diabetic animals where islets may be difficult to isolate, variable islet destruction may yield isolated islets that are not representative of the entire population. In addition, the concentration of glucose and other modulators of insulin synthesis in diabetic and control animals may be very different in vivo from that during in vitro incubation. Morphologic studies provide useful estimates of $\beta$ cell number, volume, and secretory granule content, but give no direct measure of hormone synthesis. Pancreatic content of insulin may reflect rates of synthesis, release, or more likely both. Similarly, the relationship between plasma insulin con-

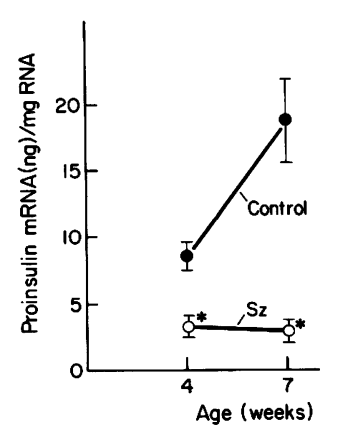

Figure 2. The concentration of proinsulin mRNA at 4 and 7 wk of age in control and streptozotocin-treated diabetic animals. This is a graphic representation of the data in Table III. ${ }^{*} P<0.001$. centration and insulin biosynthesis is not readily interpretable. Insulin synthesis has been measured by incubating whole pancreas, and this has the theoretical advantage of including all of the islets in the analysis. Yet differences in vascular perfusion, hormones, tissue hypoxia, and proinsulin mRNA degradation (see for example Fig. 4, reference 41) may complicate this type of analysis as well.

Because the labeled amino acid incorporation estimate of insulin synthesis in vivo gave a rate relative to that of total pancreatic protein, an independent measure of total pancreatic protein synthesis in diabetic and control rats was required. Total pancreatic protein synthesis was the same in both. These experiments provide the first estimate of rates of protein synthesis in rat pancreas. The fractional rate of pancreas protein synthesis was $185 \% / d$, considerably more than the rate previously determined for liver and jejunum. Pancreatic protein synthesis in 2-d-starved rats was measured because protein synthesis in liver and small intestine is diminished under these conditions (26). The reduction in the fractional rate of pancreatic protein synthesis after starvation was two- to threefold greater than the reduction in liver and intestine. In contrast with the reduction of protein synthesis in liver and intestine after starvation, pancreatic protein synthesis per milligram RNA was significantly reduced; this indicates that the reduction was caused by mechanisms in addition to diminished numbers of ribosomes. A specific reduction in pancreatic protein synthesis might be anticipated since one would predict that synthesis of digestive enzymes might be inducible with fasting and feeding (42). Thus, rates of protein synthesis are higher in pancreas than in other tissues and seem very sensitive to nutritional status.

RNA blot hybridization analysis allows quantitative assessment of proinsulin mRNA concentration in total pancreatic RNA. The exact relationship between proinsulin mRNA and insulin biosynthesis has not been determined, but in all conditions studied to date there has been a direct correlation. Fasted animals had an $80 \%$ reduction in proinsulin mRNA that was

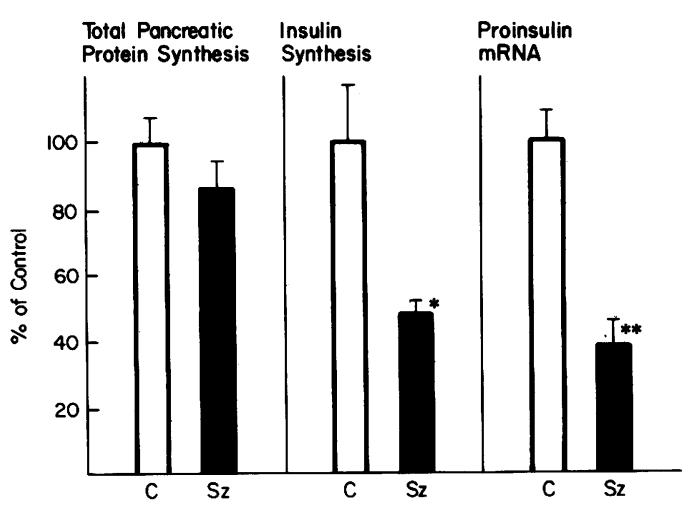

Figure 3. Total pancreatic protein synthesis, insulin synthesis, and proinsulin mRNA in streptozotocin-treated (Sz) diabetic rats at 4 wk of age as a percentage of that in control (C) animals. This is a graphic representation of the data presented in Tables II and III. ${ }^{*} P<0.005 ;{ }^{* *} P<0.001$. 
rapidly restored to normal upon refeeding $(30,33)$. Similarly, plasma and pancreatic insulin have been noted to be decreased, as has insulin biosynthesis (assessed only on isolated islets), in fasted rats $(43,44)$. Glucose injection specifically increased proinsulin mRNA (31) and proinsulin biosynthesis (34). Dexamethasone (a synthetic glucocorticoid) injection for $4 \mathrm{~d}$ produced a twofold increase in both proinsulin mRNA and insulin biosynthesis measured in vivo (manuscript in preparation). These studies do not exclude the possibility that changes in insulin biosynthesis may also occur at the translational level. In fact, translational control is important in acute (1-2 h) changes in insulin biosynthesis in vitro (45). Similarly, changes in proinsulin mRNA may not reflect changes in insulin biosynthesis under every circumstance because translation could be rate limiting under certain conditions (46). Despite these reservations, changes in the concentration of proinsulin mRNA may be a useful indicator of the rate of insulin biosynthesis under a variety of conditions.

Estimate of insulin biosynthesis in the diabetic rat model. Streptozotocin is a potent $\beta$-cell toxin in the neonatal rat and produces a marked reduction in $\beta$-cell number and insulin content (18). After this insult the animals are able to return to normal glucose homeostasis after a short period of hyperglycemia because of $\beta$-cell replication and perhaps because of adaptive changes within $\beta$-cells after regeneration occurs. Islet number does not change, but the percentage of $\beta$-cells per islet doubles during this regenerative period. Whereas $\beta$-cell mass increased 4.6-fold in experimental animals between $4 \mathrm{~d}$ and $6 \mathrm{wk}$, compared to 2.5 -fold in controls, the absolute number of $\beta$-cells never exceeds $50-60 \%$ of controls, and between 4 and $6 \mathrm{wk}$ hyperglycemia develops. As a result of the initial injury, there is also a small but significant reduction in pancreatic content of insulin, and a marked impairment of glucose-stimulated insulin release $(18,19)$. These $\beta$-cell changes are strikingly similar to those noted in NIDD of man, though the etiology of the two syndromes may be entirely different.

In this animal model of NIDD, insulin synthesis in individual islets is increased (20), while that in whole pancreas measured in vivo is decreased. The in vivo analysis used rats at 4 and 7 wk, whereas the isolated islet experiments were performed on older (10-14-wk-old) animals. Since the degree of hyperglycemia and islet $\beta$-cell number change with time, the time from treatment with streptozotocin may be important. Differences in vascular perfusion, concentration of other fuels and hormones, or other factors that occur in vitro but not in vivo might also account for the differences observed. The simplest explanation is that both observations are correct. Total synthesis is reduced because of reduced $\beta$-cell mass, while the islets selected by isolation may be overstimulated by persistent hyperglycemia.

While the decrease in levels of insulin mRNA and rates for insulin biosynthesis (Table II) appear to be disproportionate with the decrease in pancreatic insulin content (Table I), this difference may be more apparent than real, because these measurements were made on different animals. The effect of streptozotocin seems to vary from batch to batch of animals. In other animals studied at similar ages, the effect of streptozotocin on pancreatic insulin content was greater $(18,19)$.

The importance of the present observation in the diabetic rat model for NIDD is that at age $4 \mathrm{wk}$, minimal elevations of plasma glucose are associated with a marked reduction in insulin biosynthesis (Table II and Fig. 3). The more than 50\% reduction in synthesis and proinsulin mRNA seems disproportionate with the more modest $(25-50 \%)$ reduction in $\beta$-cell number. This reduction in insulin synthesis is greater than is immediately apparent because streptozotocin-treated animals are hyperglycemic. Hyperglycemia is usually a potent stimulus to insulin biosynthesis $(23,31,34-40,45)$. These observations thus suggest that as the streptozotocin-treated animals grow and insulin requirements increase (47), diabetes may ensue because of a limited ability to synthesize insulin.

\section{Acknowledgments}

The authors appreciate conversations with Philippe Halban concerning these studies. The technical assistance of Cheryl Fleishmann and Keith O'Connell and the secretarial assistance of Pamela Rader are gratefully acknowledged.

This work was supported in part by grants from the National Institutes of Health (AM-20349 and AM-16746) and by a grant from the Veterans Administration (number 821).

\section{References}

1. Rotter, J. I., and D. L. Rimoin. 1981. The genetics of the glucose intolerance disorders. J. Med. (Westbury). 70:116-126.

2. Rotter, J. I., and D. L. Rimoin. 1980. Genetics. In Handbook of Diabetes Mellitus. M. Brownlee, editor. Garland STPM Press, New York. 3-93.

3. Fajans, S. S. 1979. Diabetes mellitus. In Endocrinology. L. J. DeGroot, G. F. Cahill, W. D. O'Dell, L. Martini, J. T. Potts, D. H. Nelson, E. Steinberger, and A. I. Winegrad, editors. Grune and Stratton, Inc., New York. 2:1007-1024.

4. Fajans, S. S., M. C. Coultier, and R. L. Crowther. 1978. Clinical and etiologic heterogeneity of idiopathic diabetes mellitus. Diabetes. 27:1112-1125.

5. Gepts, W., and P. M. LeCompte. 1981. The pancreatic islets of diabetes. Am. J. Med. 70:105-115.

6. Scott, D. A., and A. M. Fisher. 1938. The insulin and zinc content of normal and diabetic pancreas. J. Clin. Invest. 17:725-728.

7. Wrenshall, G. A., A. Bogoch, and R. C. Ritchie. 1952. Extractable insulin of pancreas: correlation in diabetic and non-diabetic cases. $\mathrm{Di}$ abetes. 1:87-107.

8. Ryan, W. G., T. B. Schwartz, and A. F. Nibbe. 1971. Insulin content of diabetic pancreas. Diabetes. 20:404-415.

9. Maclean, N., and R. F. Ogilvie. 1955. Quantitative estimation of the pancreatic islet tissue in diabetic subjects. Diabetes. 4:367-376.

10. Warren, K. W., J. W. Braasch, and C. W. Thurn. 1968. Diagnosis and surgical treatment of carcinoma of the pancreas. Curr. Probl. Surg. 132:3-70.

11. Priestley, J. T., M. W. Comfort, and R. Radcliffe, Jr. 1944. Total pancreatectomy for hyperinsulinism due to islet cell adenoma. Ann. Surg. 119:211-221.

12. Varughese, M. 1980. Surgery in pancreatic diabetes. In Secondary 
Diabetes: the Spectrum of the Diabetic Syndromes. S. Podolsky and M. Viswanathan, editors. Raven Press, New York. 231-237.

13. Deleted in press.

14. Lerner, R. L., and D. Porte, Jr. 1972. Acute and steady-state insulin responses to glucose in nonobese diabetic subjects. J. Clin. Invest. 51:1624-1631.

15. Halter, J. B., R. J. Graf, and D. Porte. 1979. Potentiation of insulin secretory responses by plasma glucose levels in man: evidence that hyperglycemia in diabetes compensates for impaired glucose potentiation. J. Clin. Endocrinol. Metab. 48:946-954.

16. Graber, A. L., F. C. Wood, and R. H. Williams. 1967. Serum immunoreactive insulin response during prolonged glucose infusions in nondiabetic and diabetic humans. Diabetes. 16:145-149.

17. Shen, S.-W., G. M. Reaven, and J. W. Farquhar. 1970. Comparison of impedance to insulin-mediated glucose uptake in normal subjects and in subjects with latent diabetes. J. Clin. Invest. 49:21512160 .

18. Bonner-Weir, S., D. F. Trent, R. N. Honey, and G. C. Weir. 1981. Responses of neonatal rat islets to streptozotocin: limited B-cell regeneration and hyperglycemia. Diabetes. 30:64-69.

19. Weir, G. C., E. T. Clore, C. J. Zmachinski, and S. Bonner-Weir. 1981. Islet secretion in a new experimental model for non-insulindependent diabetes. Diabetes. 30:590-595.

20. Halban, P. A., S. Bonner-Weir, and G. C. Weir. 1983. Increased proinsulin biosynthesis in islets from a rat model of non-insulin-dependent diabetes mellitus. Diabetes. 32:277-283.

21. Albert, W. G., and M. A. Permutt. 1979. Proinsulin precursors in catfish pancreatic cells. J. Biol. Chem. 254:2483-2492.

22. Lowry, O. H., N. J. Rosebrough, A. L. Farr, and R. J. Randall. 1951. Protein measurement with the Folin phenol reagent. J. Biol. Chem. 193:265-275.

23. Permutt, M. A., and D. M. Kipnis. 1972. Insulin biosynthesis. I. On the mechanism of glucose stimulation. J. Biol. Chem. 247:11941199.

24. Kakita, K., S. Giddings, and M. A. Permutt. 1982. Biosynthesis of rat insulins I and II: evidence for differential expression of the two genes. Proc. Natl. Acad. Sci. USA. 79:2803-2807.

25. Peavy, D. E., J. M. Taylor, and L. S. Jefferson. 1978. Correlation of albumin production rates and albumin mRNA levels in livers of normal, diabetic, and insulin-treated diabetic rats. Proc. Natl. Acad. Sci. USA. 75:5879-5883.

26. McNurlan, M. A., A. M. Tomkins, and P. J. Garlick. 1979. The effect of starvation on the rate of protein synthesis in rat liver and small intestine. Biochem. J. 178:373-379.

27. Beaucamp, K., and H. E. Walter. 1973. Amino acid determination in the nanomole range by tRNA charging and isotope dilution techniques. FEBS (Fed. Eur. Biochem. Soc.) Lett. 38:37-41.

28. Chirgwin, J. M., A. E. Przybyla, R. J. MacDonald, and W. J. Rutter. 1979. Isolation of biologically active ribonucleic acid from sources enriched in ribonuclease. Biochemistry. 24:5294-5299.

29. McMaster, G. K., and G. C. Carmichael. 1979. Analysis of single- and double-stranded nucleic acids on polyacrylamide and agarose gels by using glyoxal and acridine orange. Proc. Natl. Acad. Sci. USA. 74:4835-4838.
30. Wahl, G. M., M. Stern, and G. R. Stark. 1979. Efficient transfer of large DNA fragments from agarose gels to diazobenzyloxymethylpaper and rapid hybridization by using dextran sulfate. Proc. Natl. Acad. Sci. USA. 76:3683-3687.

31. Giddings, S. J., J. Chirgwin, and M. A. Permutt. 1977. Effects of glucose on proinsulin messenger RNA in rats in vivo. Diabetes. 31:624 629 .

32. Rigby, P. W., M. Dieckmann, C. Rhodes, and P. Berg. 1977. Labelling deoxyribonucleic acid to high specific activity in vitro by nick translation with DNA polymerase I. J. Mol. Biol. 113:237-251.

33. Giddings, S. J., J. Chirgwin, and M. A. Permutt. 1981. The effects of fasting and feeding on preproinsulin messenger RNA in rats. J. Clin. Invest. 67:952-960.

34. Logothetopoulos, J., and K. Jain. 1980. In vivo incorporation of $\left[{ }^{3} \mathrm{H}\right]$ leucine and $\left[{ }^{3} \mathrm{H}\right]$ tryptophan into proinsulin-insulin and other islet cell proteins in normoglycemic, hyperglycemic, and hypoglycemic rats. Diabetes. 29:801-805.

35. Permutt, M. A. 1981. Biosynthesis of insulin. In Islets of Langerhans. Academic Press, Inc., New York. 75.

36. Steiner, D. F., and P. B. Oyer. 1967. The synthesis of insulin and a probable precursor of insulin by a human islet cell adenoma. Proc. Natl. Acad. Sci. USA. 57:473-480.

37. Morris, G. E., and A. Korner. 1970. RNA synthesis and the stimulation of insulin biosynthesis by glucose. FEBS (Fed. Eur. Biochem. Soc.) Lett. 10:165-168.

38. Lin, B. J., M. J. Henderson, B. B. Levin, B. R. Nagy, and E. M. Nagy. 1976. Effects of iodoacetate and fluoride on islet respiration and insulin biosynthesis. Horm. Metab. Res. 8:353-358.

39. Zucker, P., and J. Logothetopoulos. 1975. Persisting enhanced proinsulin-insulin and protein biosynthesis $\left({ }^{3} \mathrm{H}\right.$-leucine incorporation) by pancreatic islets of the rat after glucose exposure. Diabetes. 24:194200.

40. Brunstedt, J., and S. J. Chan. 1982. Direct effect of glucose on the preproinsulin mRNA level in isolated pancreatic islets. Biochem. Biophys. Res. Commun. 106:1383-1389.

41. Kakita, K., S. J. Giddings, P. S. Rotwein, and M. A. Permutt. 1983. Insulin gene expression in developing rat pancreas. Diabetes. 32:691-696.

42. Harding, J. D., and W. J. Rutter. 1978. Rat pancreatic amylase mRNA. J. Biol. Chem. 253:8736-8740.

43. Tijoe, T. O., and P. R. Bouman. 1976. Effect of fasting on the incorporation of [ $\left.{ }^{3} \mathrm{H}\right]$-L-phenylalanine into proinsulin-insulin and total protein in isolated rat pancreatic islets. Horm. Metab. Res. 8:261-266.

44. Bone, A. J., and S. L. Howell. 1977. Alternations in regulation of insulin biosynthesis in pregnancy and starvation studied in isolated rat islets of Langerhans. Biochem. J. 166:501-507.

45. Itoh, N., Y. Ohshima, K. Nose, and H. Okamoto. 1982. Glucose stimulates proinsulin synthesis in pancreatic islets without a concomitant increase in proinsulin mRNA synthesis. Biochem. Int. 4:315-321.

46. Cordell, B., D. Diamond, S. Smith, J. Punter, H. H. Schone, and H. M. Goodman. 1982. Disproportionate expression of the two nonallelic rat insulin genes in a pancreatic tumor is due to translational control. Cell, 31:531-542.

47. Reaven, E., D. Wright, C. E. Mondon, R. Solomon, H. Ho, and G. M. Reaven. 1983. Effect of age and diet on insulin secretion and insulin action in the rat. Diabetes. 32:175-180. 